ORIENTAL JOURNAL OF CHEMISTRY

An International Open Free Access, Peer Reviewed Research Journal

\title{
Mixed Ligand Complexes Derived from Isoniazid and Amino Acid: Preparation, Characterization and Anti-tuberculosis Assay
}

\author{
KHAWLA M. SULTAN AL-JUBOORI* \\ Department of Chemistry, College of Education for Pure Science(Ibn Al-Haitham), University of \\ Baghdad, Iraq. \\ *Correspondin author Email: khawla.mohammed57@gmail.com
}

http://dx.doi.org/10.13005/ojc/330524

(Received: June 27, 2017; Accepted: July 25, 2017)

\begin{abstract}
A range of mixed ligand complexes derived from the reaction of alanine (alan), glycine (gly)and isoniazid (ison) ligands with $\mathrm{Cr}^{+3}, \mathrm{Co}^{+2}, \mathrm{Cu}^{+2}, \mathrm{Fe}^{+3}$, and $\mathrm{Ni}^{+2}$ ions are reported. Complexes were characterized using a variety of techniques that include; FTIR, UV-Vis., HPLC, TGA, elemental analyses, chloride content, magnetic susceptibility, melting point and conductivity. The obtained results indicated the formation of complexes in a 1:1:1:1mole ratio of M:alan:gly:ison with the general formula [M(Gly)(Alan)(Ison) $\left(\mathrm{H}_{2} \mathrm{O}\right){ }_{n} \mathrm{Cl}$ ] $\mathrm{Y}\left(\mathrm{M}=\mathrm{Cr}^{+3}, \mathrm{w}=2, \mathrm{n}=1, \mathrm{Y}=\mathrm{Cl} ; \mathrm{Fe}^{+3} \mathrm{w}=0, n=3, \mathrm{Y}\right.$ $=3\left(\mathrm{NO}_{3}{ }^{-}\right) ; \mathrm{Co}^{+2}, \mathrm{w}=1, \mathrm{n}=2, \mathrm{Y}=\mathrm{Cl} ; \mathrm{Cu}^{+2}, \mathrm{w}=0, \mathrm{n}=3, \mathrm{Y}=2\left(\mathrm{NO}_{3}^{-}\right)$and $\left.\mathrm{Ni}^{+2}, \mathrm{w}=0, \mathrm{n}=3, \mathrm{Y}=2 \mathrm{Cl}\right)$. The analyses data indicated distorted octahedral geometries about metal centres. The bio-assay of the prepared complexes show a positive activity against normal tuberculosis bacteria. However, the complexes exhibit no activity against the resistance tuberculosis bacteria.
\end{abstract}

Keywords: Mixed ligand complexes, Isoniazid, Amino acids, Preparation and characterisation, Anti-tuberculosis assay.

\section{INTRODUCTION}

Isoniazid is an organic compound that available in different pharmaceutical forms, which used to prevent and treat both latent and active tuberculosis'1. Tuberculosis is a public health disease that caused several millions deaths annually worldwide ${ }^{2}$. The number of infected people in this disease have increased, in particularly immunocompromised patients. These include those who co-infected with human immunodeficiency virus (HIV), and human who are receiving anti-tumour therapy or diabetes ${ }^{3-5}$. Therefore, this critical situation has stimulated scientist to develop and explore new strategies in drug discovery to generate new agents with best performance for human health. The aim of this work is explore the influence of incorporating isoniazid in complexation, as a ligand, on the activity of the prepared complexes against tuberculosis bacteria. A series of metal-based complexes were prepared and characterised by mixing isoniazid (the active drug) with some amino acids as bio-active materials 
in presence of the central metal ion that used as a linkage between drug and amino acids. The bio-assay study shows a positive activity against normal tuberculosis bacteria. However, the complexes exhibit no activity against the resistance tuberculosis bacteria.

\section{EXPERIMENTAL}

Chemicals were obtained commercially (Aldrich) and used as received using salt sources; $\mathrm{CrCl}_{3} \cdot 6 \mathrm{H}_{2} \mathrm{O}, \mathrm{Fe}\left(\mathrm{NO}_{3}\right)_{3} \cdot 6 \mathrm{H}_{2} \mathrm{O}, \mathrm{CoCl}_{2} \cdot 6 \mathrm{H}_{2} \mathrm{O}$, $\mathrm{NiCl}_{2} \cdot 6 \mathrm{H}_{2} \mathrm{O}$ and $\mathrm{Cu}\left(\mathrm{NO}_{3}\right)_{2} \cdot 6 \mathrm{H}_{2} \mathrm{O}$. Solvents used in the synthesis were distilled from appropriate drying agent immediately prior to use.

\section{Physical measurements}

FTIR spectra were recorded as $\mathrm{KBr}$ discs using a Shimadzu 8400 S FTIR spectrophotometer from 4000-400 $\mathrm{cm}^{-1}$. Electronic spectra were measured from $200-1100 \mathrm{~nm}$ for $10^{-3} \mathrm{M}$ solutions in DMSO at $25^{\circ} \mathrm{C}$ using a Shimadzu 1700 spectrophotometer. HPLC analysis was performed on a Shimadzu LC-2010 AHT in IbnSina Company, Ministry of Industry, Baghdad, IRAQ. Melting points were obtained on an Electro-thermal Stuart melting point SMP40apparatus and are uncorrected. Elemental analyses $(\mathrm{C}, \mathrm{H}, \mathrm{N})$ for metal complexes were carried out on a Perkin-Elmer 2400 Series-II analyzer at Materials Research Centre, Ministry for Science and Technology, Baghdad, IRAQ. Metals were determined using a Shimadzu (A.A) 680 G atomic absorption spectrophotometer. Chloride content was determined using potentiometer titration method on a 686-Titrp processor665Dosimat-Metrohm Swiss. Conductivity measurements were made with DMSO solutions using a Philips $\mathrm{PW}$ at $25^{\circ} \mathrm{C}$ for complex concentration of $10^{-3} \mathrm{M}$. Magnetic susceptibility were measured with a Brucker magnet B.M.6 apparatus at $20^{\circ} \mathrm{C}$. TGA analyses were performed by Linseis instrument. Biological assay of the complexes was conducted in Baghdad Health City, tuberculosis Treatment Centre where the drug resistance bacteria and ordinary one are obtained from. Primary isolation and culturing of mycobacterium from sputum specimens were followed according to standard procedures ${ }^{6}$. Drug susceptibility testing against isoniazid was performed by the proportional method on
Löwenstein-Jensen media at concentrations of 0.2 , 0.4 and $2.0 \mu \mathrm{g} / \mathrm{ml}$, respectively. Drug resistance was defined as greater than $1 \%$ growth in the presence of $0.1 \mu \mathrm{g}$ of isoniazid per millilitre ${ }^{7,8}$. $\mathrm{NaHPO}_{4}$ standard buffer solution (0.02M) and acetonitrile were used in the HPLC analysis. For each ligand, a series of three dilutions in water ranged between 0.0001-0.01M were used to perform a calibration curve against the peak area with the following operational conditions;(i) column $\mathrm{C}_{18}$ with dimensions $250 * 4.6 \mathrm{~mm}$ and pore $5 \mu \mathrm{m}$, (ii) the mobile phase was $\left[89 \% \mathrm{NaH}_{2} \mathrm{PO}_{4}(0.02 \mathrm{M})\right.$ buffer standard solution $\mathrm{pH}-5+11 \%$ acetonitrile] for isoniazid determination and $5 \%$ acetonitrile in water solution for amino acid determination, (iii) the flow rate was $1.5 \mathrm{ml} / \mathrm{min}$. for isoniazid, while 1 $\mathrm{ml} / \mathrm{min}$. for amino acids and, (iv) the UV detector wave length was $259 \mathrm{~nm}$ in isoniazid and $210 \mathrm{~nm}$ for amino acids. The injection volume was $20 \mu \mathrm{l}$ and the operational temperature was $40^{\circ} \mathrm{C}$. Alanine, glycine and isoniazid showed peaks with retention time 6.23, 6.74 and 5.40 min, respectively.

\section{General method for preparation of complexes The complexes were prepared adopting a similar method and as follows;}

To a solution of $(0.01$ mole $)$ of the metal salt dissolved in 10-20 $\mathrm{ml}$ of deionized water, was added gradually with stirring a mixture of $(0.01$ mole) of each ligand dissolved in $10 \mathrm{ml}$ of deionized water. The reaction mixture was left stirring for $4 \mathrm{~h}$, and then the solution was allowed to evaporate on a water bath. The concentrated solution was left to stand and a coloured solid that formed was filtered, washed with cold water $(3 \mathrm{ml})$, and then recrystallized from EtOH/ $\mathrm{H}_{2} \mathrm{O}$. The coloured solid was dried under vacuum. Melting points, colours and yields of the products are listed in Table (1).

\section{RESULTS and DISCUSSION}

The mixed ligand complexes were obtained in good yields in a one-pot approach using an aqueous medium. The complexes were prepared from the reaction of $\mathrm{Cr}^{+3}, \mathrm{Co}^{+2}, \mathrm{Cu}^{+2}, \mathrm{Fe}^{+3}$, and $\mathrm{Ni}^{+2}$ with the amino acid ligands (alanine and glycine) and isoniazid. The mixed ligand complexes were prepared from mixing of $10 \mathrm{~m}$ mole of metal salt and $10 \mathrm{~m}$ mole of each ligand in an aqueous 
Table. 1: physicochemical properties of the ligands and prepared complexes

\begin{tabular}{|c|c|c|c|c|c|c|c|c|c|c|c|}
\hline \multirow[t]{2}{*}{ Comp. } & \multirow[t]{2}{*}{ Yield \% } & \multirow[t]{2}{*}{ Colour } & \multirow[t]{2}{*}{ m.p. ${ }^{\circ} \mathrm{C}$} & \multirow[t]{2}{*}{$\begin{array}{c}\text { Free Cl } \\
\text { /mole }\end{array}$} & \multirow[b]{2}{*}{ Metal } & \multicolumn{3}{|c|}{$\begin{array}{l}\text { Microanalysis } \\
\text { Found (calcd.) \% }\end{array}$} & \multicolumn{2}{|c|}{$\begin{array}{c}\text { HPLC } \\
\text { retention } \\
\text { time (min.) }\end{array}$} & \multirow[t]{2}{*}{$\begin{array}{l}\mathrm{m} \\
\mathrm{S} . \mathrm{cm}^{2} \\
. \mathrm{mol}^{-1}\end{array}$} \\
\hline & & & & & & C & $\mathbf{H}$ & $\mathbf{N}$ & $\mathrm{Cl}$ & & \\
\hline $\mathrm{Cr}$ & 68 & Purple & 185 & 1 & $\begin{array}{c}10.89 \\
(-) 10.47\end{array}$ & $\begin{array}{c}27.66 \\
(-) 27.38\end{array}$ & $\begin{array}{c}4.43 \\
(-) 4.27\end{array}$ & $\begin{array}{c}14.66 \\
(-) 14.42\end{array}$ & $\begin{array}{c}22.27 \\
(-) 21.79\end{array}$ & $(-)$ & 39.1 \\
\hline $\mathrm{Fe}$ & 59 & Light- brown & 275 & $(-)$ & $\begin{array}{c}9.35 \\
(-) 9.12\end{array}$ & $\begin{array}{c}22.12 \\
(-) 21.79\end{array}$ & $\begin{array}{c}4.22 \\
(-) 3.98\end{array}$ & $\begin{array}{c}18.76 \\
(-) 18.37\end{array}$ & $(-)$ & $(-)$ & 111.8 \\
\hline Co & 65 & Pink & 155 & 1 & $\begin{array}{c}12.64 \\
(-) 12.28\end{array}$ & $\begin{array}{l}28.34 \\
(-) 28.1\end{array}$ & $\begin{array}{c}4.76 \\
(-) 4.43\end{array}$ & $\begin{array}{c}15.02 \\
(-) 14.76\end{array}$ & $\begin{array}{c}15.21 \\
(-) 14.87\end{array}$ & $(-)$ & 60.9 \\
\hline $\mathrm{Cu}$ & 53 & Green- blue & 330 & $(-)$ & $\begin{array}{c}11.7 \\
(-) 11.24\end{array}$ & $\begin{array}{c}24.34 \\
(-) 24.07\end{array}$ & $\begin{array}{c}4.64 \\
(-) 4.38\end{array}$ & $\begin{array}{c}18.06 \\
(-) 17.81\end{array}$ & $(-)$ & $(-)$ & 54.7 \\
\hline $\mathrm{Ni}$ & 77 & Light- blue & 280 & 2 & $\begin{array}{c}12.1 \\
(-) 11.82\end{array}$ & $\begin{array}{c}27.24 \\
(-26.97\end{array}$ & $\begin{array}{c}5.2 \\
(-) 5.02\end{array}$ & $\begin{array}{c}14.44 \\
(-) 14.25\end{array}$ & $\begin{array}{c}14.62 \\
(-) 14.18\end{array}$ & $(-)$ & 48.2 \\
\hline Iso & $(-)$ & $(-)$ & & $(-)$ & & & & & $(-)$ & 5.9 & $(-)$ \\
\hline Ala & $(-)$ & $(-)$ & & $(-)$ & & & & & $(-)$ & 6.2 & $(-)$ \\
\hline Gly & $(-)$ & $(-)$ & & $(-)$ & & & & & $(-)$ & 6.8 & $(-)$ \\
\hline
\end{tabular}

medium. A range of techniques were used to confirm the entity of the prepared compounds. These include FT-IR spectra (Table 2), UV-Vis (Table 3), HPLC, elemental analyses, chloride content, conductance, melting point and magnetic moment measurements. The conductance measurements in DMSO indicated that all complexes are electrolyte $^{9}$, see Table (1), complexes are electrolyte. These measurements agree well with the following formulas:

$$
\begin{gathered}
{\left[\mathrm{CrCl}_{2}(\mathrm{Gly})(\text { Ala })(\text { Ison })\left(\mathrm{H}_{2} \mathrm{O}\right)\right] \mathrm{Cl}} \\
{\left[\mathrm{Fe}(\mathrm{Gly})(\text { Ala })(\text { Ison })\left(\mathrm{H}_{2} \mathrm{O}\right)_{3}\right]\left(\mathrm{NO}_{3}\right)_{3}} \\
{\left[\mathrm{CoCl}(\mathrm{Gly})(\text { Ala })(\text { Ison })\left(\mathrm{H}_{2} \mathrm{O}\right)_{2}\right] \mathrm{Cl}} \\
{\left[\mathrm{Ni}(\mathrm{Gly})(\text { Ala })(\text { Ison })\left(\mathrm{H}_{2} \mathrm{O}\right)_{3}\right] \mathrm{Cl}_{2}} \\
{\left[\mathrm{Cu}(\mathrm{Gly})(\text { Ala })(\text { Ison })\left(\mathrm{H}_{2} \mathrm{O}\right)_{3}\right]\left(\mathrm{NO}_{3}\right)_{2}}
\end{gathered}
$$

The physico-chemical data indicated the formation of complexes with the general formulae $\left[\mathrm{M}(\mathrm{Gly})\left(\right.\right.$ Alan) (Ison) $\left.\left(\mathrm{H}_{2} \mathrm{O}\right)_{\mathrm{n}} \mathrm{Cl}_{\mathrm{w}}\right] \mathrm{Y}\left(\mathrm{M}=\mathrm{Cr}^{+3}, \mathrm{w}=2, \mathrm{n}=\right.$ $1, \mathrm{Y}=\mathrm{Cl} ; \mathrm{Fe}^{+3} \mathrm{w}=0, \mathrm{n}=3, \mathrm{Y}=3\left(\mathrm{NO}_{3}{ }^{-}\right) ; \mathrm{Co}^{+2}, \mathrm{w}=1, \mathrm{n}$ $=2, \mathrm{Y}=\mathrm{Cl} ; \mathrm{Cu}^{+2}, \mathrm{w}=0, \mathrm{n}=3, \mathrm{Y}=2\left(\mathrm{NO}_{3}{ }^{-}\right)$and $\mathrm{Ni}^{+2}, \mathrm{w}$ $=0, n=3, Y=2 \mathrm{Cl}$ ). Complexes were isolated as solids, air-stable that showed solubility in high polar solvents such; $\mathrm{H}_{2} \mathrm{O}$, DMF, DMSO, and insoluble in the low polar ones. The coordination spheres of the complexes were assumed from their spectra (FTIR, UV-Vis), magnetic susceptibility, HPLC, metal and chloride content and TGA, see Figure. 1.

\section{HPLC and chloride content analysis}

HPLC technique was used to clarify the amount of the unreacted organic ligands after complex formation. The HPLC data of glycine (gly), alanine (alan), and isoniazid (ison) have shown retention times of $6.75,6.23$ and $5.88 \mathrm{~min}$., respectively. A calibration curve based on a series of standard organic ligands in aqueous solutions was established. The HPLC data indicated that; there is no free ligands remain after the reaction of 1 equivalent of metal ion in an aqueous solution with a mixture of 1 equivalent of each ligand, confirming the involvement of the three ligands in complexation, equation (1):

$$
\mathrm{M}^{+} \mathrm{n}+\mathrm{Gly}+\mathrm{Ala}+\text { Ison } \stackrel{\mathrm{H}_{2} \mathrm{O}}{\rightarrow}\left[\mathrm{M}(\mathrm{Gly})(\text { Ala })(\text { Ison })^{+\mathrm{n}}\right.
$$

The analytical data of checking on the ionic chloride content using $\mathrm{AgNO} 3$ solution indicated the precipitation of a 1 equivalent of chloride ion in the $\mathrm{Co}$ (II) and $\mathrm{Cr}$ (III) complexes, and 2 equivalents in the $\mathrm{Ni}(\mathrm{II})$. Therefore, the previous stoichiometry equation for these complexes can be redraw as follows, equation (2-4):

$$
\begin{gathered}
\mathrm{H}_{2} \mathrm{O} \\
\mathrm{CoCl}_{2}+\mathrm{Gly}+\mathrm{Ala}+\mathrm{IsON} \rightarrow\left[\mathrm{CoCl}(\mathrm{Gly})(\mathrm{Ala})(\mathrm{IsON})^{+}+\mathrm{Cl}\right. \\
\mathrm{H}_{2} \mathrm{O} \\
\mathrm{CrCl}_{3}+\mathrm{Gly}+\mathrm{Ala}+\mathrm{ISON} \rightarrow\left[\mathrm{CrCl}(\mathrm{Gly})(\mathrm{Ala})(\mathrm{IsON})^{+}+\mathrm{Cl}\right. \\
\mathrm{H}_{2} \mathrm{O} \\
\mathrm{NiCl}_{2}+\mathrm{Gly}+\mathrm{Ala}+\mathrm{ISON} \rightarrow\left[\mathrm{Ni}(\mathrm{Gly})(\mathrm{Ala})(\mathrm{IsON})^{+2}+2 \mathrm{Cl}\right.
\end{gathered}
$$



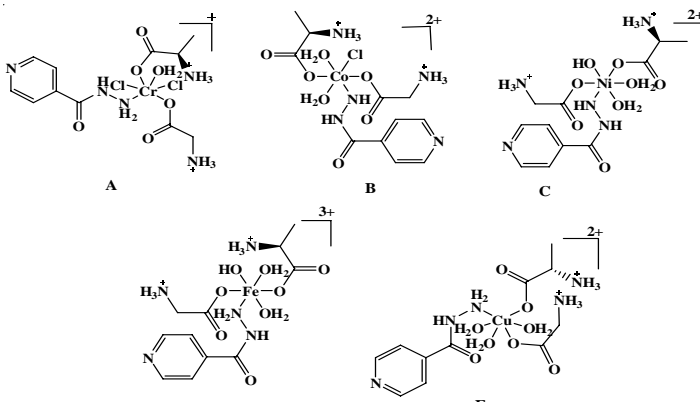

Fig. 1. The proposed structures of; A) $\mathrm{Cr}$ (III)complex, B) $\mathrm{Co}$ (II)-complex, C) Ni(II)-complex, D) $\mathrm{Fe}(\mathrm{III})$-complex and $\mathrm{E}) \mathrm{Cu}(\mathrm{II})$-complex

\section{FT-IR spectra}

The FTIR data of the complexes and their ligands are listed in Table (2). The FTIR spectra of the free alanine and glycine amino acid display peaks at 1593, 1412 and 1595 and $1412 \mathrm{~cm}^{-1}$ assigned to $v_{\text {as }}\left(\mathrm{COO}^{-}\right)$and $\mathrm{v}_{\mathrm{s}}\left(\mathrm{COO}^{-}\right)$, respectively. These bands were shifted to higher frequencies in the spectra of $\mathrm{Cr}(\mathrm{III}), \mathrm{Co}(\mathrm{II}), \mathrm{Fe}(\mathrm{III})$ and $\mathrm{Ni}(\mathrm{II})$ (Fig. (1, 2, 4 and 5) and appeared in the range 15951618 and $1412-1418 \mathrm{~cm}^{-1}$ for $v_{\text {as }}\left(\mathrm{COO}^{-}\right)$and $v_{s}(\mathrm{COO})$, respectively. However, in the $\mathrm{Cu}(\mathrm{II})$ complex, Fig. (3), these bands were shifted to lower frequencies and appeared at 1580 and $1416 \mathrm{~cm}^{-1}$. The shift to higher wave number, compared with that in the free amino acid ligands, can be attributed to a weak linkage between the carboxylate groups in the amino acids and metal ion. While, shifting to lower wave number, compared with that in the free amino acid ligands, is related to delocalisation of metal electron density $\left(t_{2 g}\right)$ to the $\pi$-system of the ligands ${ }^{10}$. The differences between the asymmetric and symmetric vibration of - $\mathrm{COO}^{-}$group for both amino acids in all complexes is laying between $164-206 \mathrm{~cm}^{-1}$. This is in accordance with results indicated the carboxylate group coordinated to a metal ion in a monodentate fashion ${ }^{11}$. The spectra of complexes indicated peaks around ca. 3100 $\mathrm{cm}^{-1}$, similar to that recorded in the spectra of amino acid ligands, which assigned to $v\left(\mathrm{NH}_{3}{ }^{+}\right)$group. This result indicated that amino acid ligands behaved as a zwitter ion species upon complexation. Therefore, they behave as neutral ligands.

The FTIR spectrum of isoniazid shows peak at $3304 \mathrm{~cm}^{-1}$ related to i $(\mathrm{N}-\mathrm{H})$ group. This peak appeared as a broaden in the spectra of the complexes, indicating the involvement of the nitrogen atom in complexation. Further, the FTIR spectrum indicated peak at $1668 \mathrm{~cm}^{-1}$ assigned to $v(\mathrm{C}=\mathrm{O})$ group. This band was shifted to lower frequency in all complexes, except that for $\mathrm{Cu}(\mathrm{II})$ complex, which shifted to higher frequency. This shifting indicated the involvement of the isoniazid moiety in complexation. More, the isoniazid moiety coordinate to the metal centre as a neutral species.

Table. 2: IR frequencies $\left(\mathrm{cm}^{-1}\right)$ of the compounds.

\begin{tabular}{|c|c|c|c|c|c|c|c|c|c|c|c|}
\hline Comp. & $\begin{array}{c}v_{\text {asyl }} \\
(\text { COO- })\end{array}$ & $\begin{array}{c}v_{\text {sym }} \\
(\text { COO-) }\end{array}$ & $\begin{array}{c}v_{\text {asy }} \\
\left(\mathrm{NH3}^{+}\right) \\
\text {Ala, Gly }\end{array}$ & $\begin{array}{c}v_{\text {sym }} \\
\left(\mathrm{NH3} 3^{+}\right) \\
\text {Ala, Gly }\end{array}$ & $\begin{array}{c}\text { Ala v } \\
\left(\mathrm{NH}^{+}\right)\end{array}$ & $\begin{array}{c}\text { Gly- v } \\
\left(\mathrm{NH}^{+}\right)\end{array}$ & $v(\mathrm{~N}-\mathrm{H})$ & $v(C=0)$ & $v(M-N)$ & $v(M-0)$ & $\begin{array}{l}\Delta\left(v_{\text {as }}\right. \\
\left.-v_{\text {sy }}\right)\end{array}$ \\
\hline Ala & 1593 & 1412 & - & 2604 & & & & & & & \\
\hline Gly & 1595 & 1412 & $\begin{array}{r}3159 \\
\text { and }\end{array}$ & 2823 & 2604 & & 3304 & & & & \\
\hline Ison & & & 3078 & & & & & 1668 & & & \\
\hline $\mathrm{Cr}$ & 1618 & 1412 & 3103 & 2617,2729 & 2823 & 1649 & & 1668 & 415 & 496 & 206 \\
\hline Co & 1595 & 1418 & -3123 & 2619,2870 & 2617 & 2729 & & 1668 & 415 & 496 & 177 \\
\hline $\mathrm{Cu}$ & 1580 & 1416 & $\begin{array}{c}3200 \\
\text { and } \\
3000\end{array}$ & 2610,2830 & 2619 & 2870 & & 1668 & 415 & 496 & 164 \\
\hline $\mathrm{Fe}$ & 1608 & 1418 & $\begin{array}{c}3196 \\
\text { and } \\
3062\end{array}$ & 2610,2839 & 2610 & 2830 & & 1668 & 415 & 496 & 190 \\
\hline $\mathrm{Ni}$ & 1595 & 1412 & $\begin{array}{r}3127 \\
\text { and } \\
3055\end{array}$ & -, 2866 & 2610 & 2839 & & 1668 & 415 & 496 & 183 \\
\hline
\end{tabular}


The spectra of the complexes revealed new peaks in the range 400-430 and $459-511 \mathrm{~cm}^{-1}$ that assigned to $i(M-N)$ and $v(M-O)$, respectively, which indicated that both the nitrogen of isoniazid and carboxylate of amino acids were coordinated to the metal centre ${ }^{12}$. Further, the spectra of ligands and complexes indicated a strong hydrogen bonding that appeared as medium broad band above $3400 \mathrm{~cm}^{-1}$. Further, this band includes the $(\mathrm{OH})$ and $(\mathrm{NH})$ stretching of the water and the amine fragments. In the $\mathrm{Fe}(\mathrm{III})$ and $\mathrm{Cu}$ (II) complexes, the spectra indicated peaks at 1517-1560 and 1334$1342 \mathrm{~cm}^{-1}$ related to the ionic $\mathrm{NO}_{3}$-group, see Table (2).

\section{Electronic spectra and magnetic moment measurement}

The electronic spectra of the complexes exhibited bands related to the $\pi \rightarrow \pi^{*}$ and $n \rightarrow \pi^{*}$ transitions. The $\mathrm{Cr}$ (III)-complex showed additional peaks at 552 and $683 \mathrm{~nm}$ related to ${ }^{4} \mathrm{~A}_{2} \mathrm{~g}^{(\mathrm{F})} \rightarrow{ }^{4} \mathrm{~T}_{1} \mathrm{~g}^{(\mathrm{F})}$ and ${ }^{4} \mathrm{~A}_{2} \mathrm{~g}^{(\mathrm{F})} \rightarrow{ }^{4} \mathrm{Tg}^{(\mathrm{F})}$ transitions, respectively indicating an octahedral arrangement about metal centre ${ }^{13}$. The magnetic moment value $3.73 \mathrm{BM}$ confirmed octahedral geometry around metal ion ${ }^{12}$. The $\mathrm{Co}$ (II)complex, showed additional peaks at 462 and 502 $\mathrm{nm}$, type ${ }^{4} \mathrm{~T}_{1} \mathrm{~g}^{(\mathrm{P})} \rightarrow{ }^{4} \mathrm{~T}_{1} \mathrm{~g}^{(\mathrm{P})}$ and ${ }^{4} \mathrm{~T}_{1} \mathrm{~g}^{(\mathrm{F})} \rightarrow{ }^{4} \mathrm{~A}_{1} \mathrm{~g}^{(\mathrm{F})}$, respectively. This result with the magnetic moment value 4.45 $\mathrm{BM}$ confirmed an octahedral geometry around $\mathrm{Co}$ atom ${ }^{14}$. The $\mathrm{Cu}$ (II)-complex, Fig. (8), showed additional peaks at $710 \mathrm{~nm}$ correlated to ${ }^{2} \mathrm{Eg} \rightarrow{ }^{2} \mathrm{~T}_{2} \mathrm{~g}$ transition that confirmed a distorted octahedral arrangement about the $\mathrm{Cu}$ atom. The magnetic moment value $1.72 \mathrm{BM}$ confirmed octahedral geometry around metalion ${ }^{15}$. The $\mathrm{Fe}$ (III) and $\mathrm{Ni}(\mathrm{II})$-complexes, Fig. (9 and 10), showed additional peaks at 520, 380 and $630 \mathrm{~nm}$, type ${ }^{6} \mathrm{~A}_{1} \mathrm{~g} \rightarrow{ }^{2} \mathrm{Eg} \mathrm{g}^{(\mathrm{G})}, \quad{ }^{3} \mathrm{~A}_{2} \mathrm{~g} \rightarrow{ }^{3} \mathrm{~T}_{1} \mathrm{~g}^{(\mathrm{P})}$ and $\mathrm{A}_{2} \mathrm{~g} \rightarrow{ }^{3} \mathrm{~T}_{1} \mathrm{~g}$, respectively. The magnetic moment values 4.33 and 2.88 BM confirmed distorted octahedral geometries around $\mathrm{Fe}(\mathrm{III})$ and $\mathrm{Ni}(\mathrm{II})$ centres, respectively ${ }^{16}$ (see Table 3).

Table. 3: Electronic spectral data in DMSO solutions.

\begin{tabular}{|c|c|c|c|c|c|}
\hline \multirow[t]{2}{*}{ Band } & \multicolumn{2}{|c|}{ Wave number } & \multirow{2}{*}{$\underset{\mathrm{dm}^{3} \mathbf{m o l}^{-1} \mathbf{c m}^{-1}}{\varepsilon}$} & \multirow[t]{2}{*}{ Assignment } & \multirow[t]{2}{*}{ Geometry } \\
\hline & $\lambda(\mathrm{nm})$ & $\lambda\left(\mathrm{cm}^{-1}\right)$ & & & \\
\hline \multicolumn{6}{|c|}{ Cr(III)-complex. } \\
\hline 1 & 265 & 37736 & $2.7{ }^{*} 10^{3}$ & \multirow{4}{*}{ 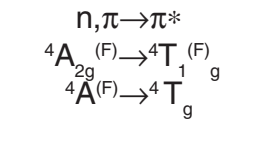 } & \multirow{3}{*}{$\begin{array}{c}\text { Distorted } \\
\text { octahedral }\end{array}$} \\
\hline 2 & 552 & 18116 & 180 & & \\
\hline 3 & 683 & 14641 & 112 & & \\
\hline \multicolumn{5}{|c|}{ Co(II)-complex. } & \\
\hline 1 & 264 & 37879 & $3.3 * 10^{3}$ & \multirow{5}{*}{ 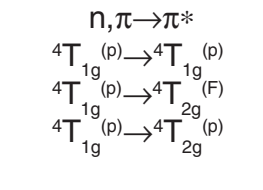 } & \multirow{5}{*}{$\begin{array}{l}\text { Distorted } \\
\text { octahedral }\end{array}$} \\
\hline 3 & 462 & 21645 & 198 & & \\
\hline 4 & 502 & 19920 & 226 & & \\
\hline 5 & 1095 & 9132 & 30 & & \\
\hline \multicolumn{4}{|c|}{ Cu(II)-complex. } & & \\
\hline 1 & 262 & 38168 & $1.3 * 10^{3}$ & $\mathrm{n}, \pi \rightarrow \pi^{*}$ & \multirow{3}{*}{$\begin{array}{c}\text { Distorted } \\
\text { octahedral }\end{array}$} \\
\hline 2 & 710 & 14085 & 179 & ${ }^{2} \mathrm{E}_{\mathrm{q}} \rightarrow{ }^{2} \mathrm{~T}_{2 \mathrm{q}}$ & \\
\hline \multicolumn{5}{|c|}{$\mathrm{Fe}(\mathrm{III})$ - complex. } & \\
\hline 1 & 269 & 37175 & $1.5 * 10^{3}$ & $\mathrm{n}, \pi \rightarrow \pi^{*}$ & \multirow{3}{*}{$\begin{array}{l}\text { Distorted } \\
\text { octahedral }\end{array}$} \\
\hline 2 & 520 & 19231 & 106 & ${ }^{6} \mathrm{~A}_{1 \mathrm{~g}} \rightarrow{ }^{2} \mathrm{E}_{\mathrm{g}}(\mathrm{G})$ & \\
\hline 3 & 930 & 10753 & 12 & ${ }^{6} \mathrm{~A}_{1} \cdot\left({ }^{6} \mathrm{~S}\right)^{4} \rightarrow \mathrm{T}_{1}\left({ }^{4} \mathrm{G}\right)$ & \\
\hline \multicolumn{6}{|c|}{$\mathrm{Ni}(\mathrm{II})$-complex. } \\
\hline 1 & 264 & 37879 & $3.6 * 10^{3}$ & $\mathrm{n}, \pi \rightarrow \pi *$ & \multirow{4}{*}{$\begin{array}{l}\text { Distorted } \\
\text { octahedral }\end{array}$} \\
\hline 2 & 380 & 26316 & 501 & ${ }^{3} \mathrm{~A}_{2 \mathrm{~g}} \rightarrow{ }^{3} \mathrm{~T}_{1 \mathrm{~g}}^{(\mathrm{p})}$ & \\
\hline 3 & 630 & 15873 & 31 & ${ }^{3} A_{2 g} \rightarrow{ }^{3} T_{19}^{9}$ & \\
\hline 4 & 1025 & 9756 & 36 & ${ }^{4} \mathrm{~A}_{2 g}^{-g} \rightarrow{ }^{4} \mathrm{~T}_{2 g}^{\mathrm{g}}$ & \\
\hline
\end{tabular}




\section{Thermal decomposition of $\mathrm{Fe}$ (III) and $\mathrm{Ni}$ (II)complexes}

The TGA thermal analysis curve for $\left[\mathrm{Fe}(\mathrm{Ala})(\mathrm{Gly})(\right.$ Ison $\left.)\left(\mathrm{H}_{2} \mathrm{O}\right)_{3}\right]\left(\mathrm{NO}_{3}\right)_{3}$ complex is shown in Fig. 2. The complex decomposes in three steps, from 90 to $594.9^{\circ} \mathrm{C}$. The complex undergoes a rapid decomposition and weight loss initially at $160.3^{\circ} \mathrm{C}$ (obs. $=12.0833 \%$, calc. $=11.9518 \%$ ) related to loss $\left(3 \mathrm{H}_{2} \mathrm{O}+\mathrm{NH}_{3}\right)$ molecules. This mass loss could be attributed to the elimination of and ammonia species. This is in agreement with results reported previously in literature ${ }^{16-18}$. The second decomposition step refers to the loss of $\left(\mathrm{C}_{6} \mathrm{H}_{5} \mathrm{~N}+\mathrm{CO}+\mathrm{N}_{2} \mathrm{H}_{2}+3 \mathrm{CO}_{2}+\mathrm{O}_{2}+\mathrm{CH}_{3} \mathrm{CN}\right)$ segment with weight loss (obs. $=57.1328$, calc. $=56.8975 \%$ ), at $323^{\circ} \mathrm{C}$ ). The final weight of the compound observed with 28.8015 (calc. $=30.43775 \%$ ) related to $\left(\mathrm{Fe}+\mathrm{H}_{3} \mathrm{O}+3 \mathrm{NO}\right)$.

The TGA thermal analysis curve for [Ni(Ala)(Gly)(Ison) $\left.\left(\mathrm{H}_{2} \mathrm{O}\right)_{3}\right] \mathrm{Cl}_{2}$ complex is depicted in Fig. 3. The complex decomposed in three steps, from 95 to $593.7^{\circ} \mathrm{C}$. The complex undergoes a rapid decomposition and weight loss at (obs. $=11.8463 \%$, calc. $=11.2028 \%$ ). The mass loss occurred may relate to losing of $3 \mathrm{H}_{2} \mathrm{O}$ molecules, which related to the loss of three aqua water molecules. This is in agreement with results reported previously in literature ${ }^{9,10}$. The second and third decomposition steps refer to the loss of $\left(2 \mathrm{CO}_{2}+2 \mathrm{~N}_{2}+\mathrm{CO}\right)$ and $\left(\mathrm{C}_{6} \mathrm{H}_{5} \mathrm{~N}+\mathrm{Cl}_{2}\right)$ molecules, with weight loss (obs. = 35.3517 , calc. $=35.2697 \%$ ), at $454.5^{\circ} \mathrm{C}$ ) and (obs. $=30.5574$, calc. $=31.1203 \%)$, at $593.7^{\circ} \mathrm{C}$, respectively.

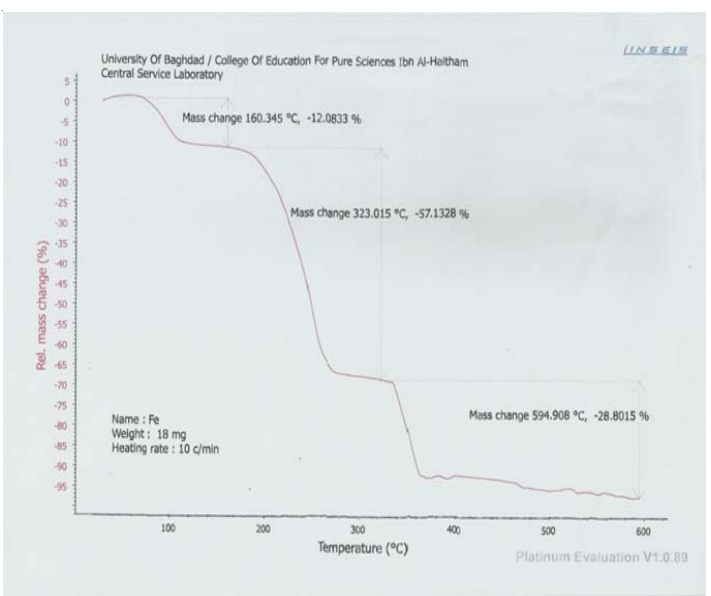

Fig. 2.TGA thermogram of $\mathrm{Fe}(\mathrm{III})$-complex in nitrogen with heating rate of $20^{\circ} \mathrm{C} \mathrm{min}{ }^{-1}$.

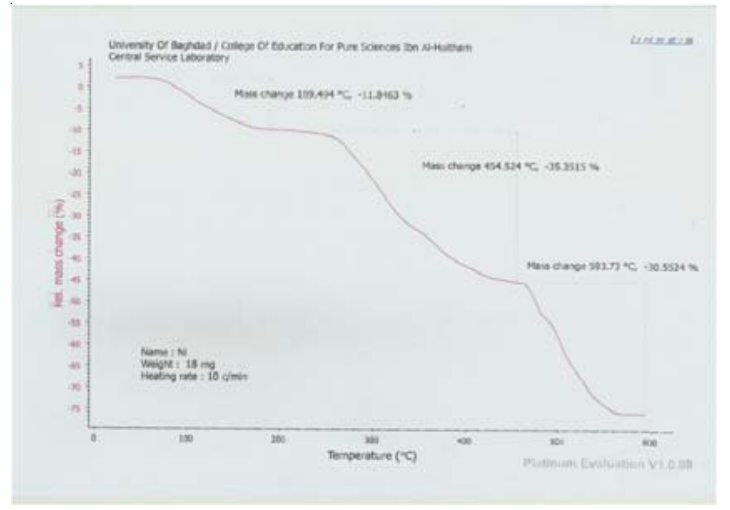

Fig. 3. TGA thermogram of $\mathrm{Ni}(\mathrm{II})$-complex in nitrogen with heating rate of $20^{\circ} \mathrm{C} \mathrm{min}-1$.

The differences in the calculated and observed weight may be related to oxidation upon thermal decomposition. This is in agreement with results reported previously in literature ${ }^{19,20}$.

\section{Biological assay}

The biological assay data of the complexes against sensitive and resistance tuberculosis bacteria are listed in Table (4). The obtained results indicated the complexes have a similar activity, compared with the original isoniazid drug which is active against sensitive bacteria and did not affect the resistance ones, see Fig. 4. This may indicate that upon testing complexes, in vivo or in vitro, they intend to liberate the isoniazid drug in to the biological system. This will lead to the formation of more stable complexes in which the amino acids act as a bidentate chelate ligand.

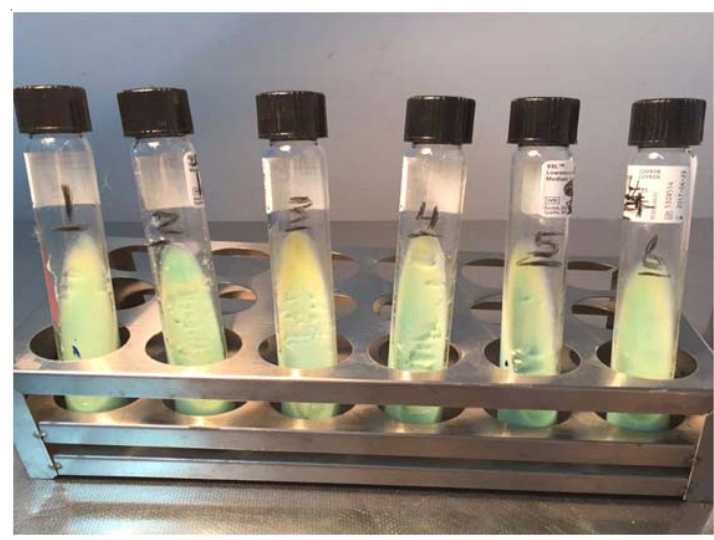

Fig. 4. Biological assay of the prepared complexes;6- growth controller, 1- Fe complex, 2Cr complex, 3-Ni complex, 4- Co complex and 5-Cu complex. 
Further, this result may indicate the need to examine the formation of complexes at different $\mathrm{pH}$ and elucidate the geometry and stability of complexes, forming upon testing stable complexes containing isoniazid ligand.

Table. 4 :Biological assay of the prepared complexes.

\begin{tabular}{lcc}
\hline \multirow{2}{*}{ Compound } & \multicolumn{2}{c}{ Bacteria growth } \\
& Resistance & Sensitivity \\
\hline $\mathrm{Cr}$ & - & + \\
$\mathrm{Co}$ & - & + \\
$\mathrm{Cu}$ & - & + \\
$\mathrm{Fe}$ & - & + \\
$\mathrm{Ni}$ & - & + \\
Iso & - & + \\
\hline
\end{tabular}

\section{CONCLUSION}

In this paper, the synthesis of mixed ligands complexes derived from two amino acids and isoniazid ligands are reported. The complexes were prepared by mixing with stirring an equivalent amount of each amino acids and isoniazid with the appropriate metal chloride or nitrate salts. Physicochemical analysis indicated the formation of six coordinate species in which the geometry around metal centre is a distorted octahedral. Bio-assay study revealed these complexes showed a similar effect against tuberculosis bacteria, compared with the isoniazid compound.

\section{REFERENCES}

1. Pilon,S.Medicines SansFrontieres. 2016.

2. Schmir, K. M.;Wansaula, Z.; Prarr,R, F.; Price, S.; Langer, A. J.,Centers for Disease Control and Prevention, Morbidity and Mortality Weekly Report. 2017, 66, (11), 289- 309.

3. Harries, A.; Maher, D.; Graham, S. TB/HIV a Clinical Manual, $2^{\text {nd }}$ edition, WHO Library Cataloguing-in-Publication Data. 2004.

4. Christopoulos, A.; Katsarou, I.; Christopoulos, I., Eur.Respir. J.2013, 42, (57), 4490.

5. Pereira, S.; Araujo, G.; Santos, C.; Oliveira, M.; Barreto, M.Revista de Saude Publica. 2016, 50, (82), 1-7.

6. Espasa, M.; González-Martín, J.; Alcaide, F.; Aragón, L. M.; Lonca, J.; Manterola, J. M.; Salvadó, M.; Tudó, G.; Orús, P.; Coll, P.J Antimicrob.Chemother. 2005, 55, (6): 860-865.

7. Merza, M.; Farnia, P.; Salih, A.; Masjedia, M.; Velayatia, A.Chemotherapy. 2010, 56, (3), 248-257.

8. Velayati, A.; Farnia, P.; Masjedi, M.; Ibrahim, T.; Tabarsi, P.; Haroun, R.Eur. Respir. J.2009, 34, (5), 1202-1203.

9. Geary, W.J., Coord. Chem. Rev. 1971, 7, (1), 81-122.

10. Poggi, M.; Barroso, R.; Costa-Filho,A. J.;de Barros, H. B.;Pavan, F.;Leite, C. Q.;Gambino, D.; Torre, M. H.J. Mex. Chem. Soc. 2013, 57, (3), 198-204.
11. Al-Jeboori, M. J.; Al-Dujaili, A. H.; and AlJanabi, A., Transition Metal Chemistry. 2009, 34,(1), 109-113.

12. Ahmed, R. M.; Hamdan, T. A.; Numan, A. T.; Al-Jeboori, M. J.;Potgieter, H.Complex Met.2014, 1, 1, 38-45,

13. Ahmed, R. M.; Yousif, E. I.; Hasan, H. A.; AlJeboori, M. J.The Scientific World Journal: Inorganic Chemistry. 2013,1-7.

14. Sancak, K.; Mustafa Er.;Unver, Y.; Yildirim, M.;Degirmencioglu, I. Transition Metal Chemistry. 2007, 32, 16-22.

15. Abdul-Ghani, A. J.; Al-Jeboori, M. J.; AlKarawi, A.J.J. Coord. Chem., 2009, 62, 16, 2736-2744.

16. Nakamoto, K. $5^{\text {th }}$ edition, John Wiley and Sons Inc., New York. 2002.

17. Ma, Q.; Zhu, M.; Feng, L. L.; Yan, Y. Inorg. Chem. Acta. 2011, 370, 102-107.

18. Rosadoa, M. S.; Leonor, M.;Duarte, R.S.; Fausto, R. Journal of Molecular Structure. 1997, 410-411, 343-348.

19. Rosadoa, M. S.; Leonor,M.; Duarte, R.S.; Fausto, R. Vibrational Spectroscopy. 1999, 16, 35-54.

20. Guanasekaran, S.; Sailatha, E.; Seshadri, S.; Kumaresan, S. Indian Journal of Pure \& Applied Physics.2009, 47, 12-18. 